\title{
Gross morphology of rhea oropharyngeal cavity ${ }^{1}$
}

\author{
Marcio N. Rodrigues ${ }^{2}$, Catarina N. Tivane ${ }^{2}$, Rafael C. Carvalho ${ }^{2,3 *}$, Gleidson B. Oliveira ${ }^{4}$, \\ Roberto S.B. Silva ${ }^{4}$, Carlos E. Ambrosio ${ }^{5}$, Moacir F. Oliveira ${ }^{4}$ and Maria A. Miglino ${ }^{2}$
}

\begin{abstract}
Rodrigues M.N., Tivane C.N., Carvalho R.C., Oliveira G.B., Silva R.S.B., Ambrosio C.E., Oliveira M.F \& Miglino M.A. 2012. Gross morphology of rhea oropharingeal cavity. Pesquisa Veterinária Brasileira 32(Supl.1):53-59. Universidade Federal do Maranhão, BR 222 Km 4, Chapadinha, MA 65500-000, Brazil. E-mail: rafaelcarvalho@ufma.br

The rhea (Rhea americana americana) is an american bird belonging to Ratite's family. Studies related to its morphology are still scarce. This study aims to describe the macroscopic structures of the oropharyngeal cavity. Five heads (2 to 6 months old) formalin preserved were anatomically dissected to expose the oropharynx. The oropharynx of the rhea was "bell-shaped" composed by the maxillary and mandibular rhamphotheca. The roof and floor presented two distinct regions different in colour of the mucosa. The rostral region was pale pink contrasting to grey coloured caudal region. The median longitudinal ridge extended rostrally from the apex of the choana to the tip of the beak in the roof and it is clearly more prominent and rigid than the homolog in the floor that appeared thin and stretched merely along the rostral portion of the regio interramalis. The floor was formed by the interramal region, (regio interramalis) tongue and laryngeal mound containing glove-shaped glottis. This study confirmed the basic morphology of the oropharinx of the rhea. However, important morphological information not previously described is highlighted and contradictory information present in the literature is clarified.
\end{abstract}

INDEX TERMS: Morphology, oropharingeal cavity, Rhea.

RESUMO.- [Macroscopia da orofaringe de Ema.] A ema é uma ave Americana pertencente à familia das Ratitas. Estudos relacionados a sua morfologia são escassos. 0 objetivo deste estudo foi descrever as estruturas macroscópicas da cavidade orofaríngea. Cinco cabeças (dois a seis meses de idade) de emas fixadas em formol foram dissecadas para a exposição da orofaringe. A orofaringe das emas apresentou formato de "sino" composta pela ranfoteca maxilar e mandibular. 0 teto e o assoalho apresentavam duas regiões distintas com diferenças na coloração da mucosa. A região

\footnotetext{
${ }^{1}$ Received on August 4, 2012.

Accepted for publication on October 8, 2012.

${ }^{2}$ Departamento de Cirurgia, Faculdade de Medicina Veterinária e Zootecnia (FMVZ), Universidade de São Paulo (USP), Av. Prof. Dr. Orlando Marques de Paiva 87, Cidade Universitária, São Paulo, SP 05508-900, Brazil.

${ }^{3}$ Centro de Ciências Agrárias e Ambientais, Universidade Federal do Maranhão, BR 222 Km 4, Chapadinha, MA 65500-000, Brazil. *Corresponding author: rafaelcarvalho@ufma.br

${ }^{4}$ Departamento de Ciência Animal, Universidade Federal Rural do Semi-Árido, Av. Francisco Mota 572, Bairro Costa e Silva, Mossoró, RN 59625900, Brazil.

${ }^{5}$ Faculdade de Zootecnia e Engenharia de Alimentos (FZEA), Campus da USP, Av. Duque de Caxias Norte 225, Pirassununga, SP 13635-900, Brazil.
}

rostral era rosa clara contrastando com a coloração cinza da região caudal. A linha longitudinal mediana se estendia rostralmente do ápice da coana ate a extremidade do bico no teto e esta era bem proeminente e rígida quanto a mesma estrutura no assoalho, esta apresentou-se estendida ao longo da porção rostral da região interramal. 0 assoalho estava formado pela região interramal, língua, glote e cartilagens da laringe com formato de dedos de luvas. 0 estudo confirma a morfologia básica da orofaringe das emas. Entretanto, importantes informações morfológicas não descritas anteriormente são destacadas e informações contraditórias presentes na literatura são esclarecidas.

TERMOS DE INDEXAÇÃO: Morfologia, orofaringe, Rhea americana americana.

\section{INTRODUCTION}

The rhea (Rhea Americana americana) belongs to the Ratites Family, together with the Ostrich (Struthio camelus), Emu (Dromaius novaehollandiae), Kiwi (Apteryx australis) and Cassowary (Cassuaris casuarius). Among these species, the Ostrich, Emu and Rhea are commercially important, fact that supports the interest of scientist in studies rela- 
ted with these birds (Giannoni 1997, Sales et al. 2000, Morata 2004). In Giannoni (1997) studies differences in size and height between ratites are emphasized. Fowler (1991) reported the occurrence of different anatomical features amongst rhea and other ratites. In Brasil three subspecies of Rhea are founded. Rhea americana americana commonly found at Northern, Southern, Center-west and North of Paraná, Rhea americana intermédia, founded in Rio Grande do Sul, Santa Catarina and South of Paraná, and Rhea americana albescens, which is native from Southern of Mato Grosso do Sul.

Adult and rhea chicks similarly to other ratites are almost vegetarian, but they can also eat small stones, insects and small vertebrate, thus considered very important specie in the maintenance of the ecologic environment (Sick 1985, Mello 1987).

Despite fluctuations in the commercialization of native wildlife, in Brazil, the sustainable development for conservation of wild animals has been gained valuable significance as well as in other parts of the world. Thus, Brazil has become one of the principal exporters of meat, skin and feathers coming primarily from ostrich and emu industry. Capybara (Hydrochoerus hydrochaeris), peccary (Tayassu), paca (Cuniculus paca), broad-snouted caiman (Caiman latirostris) and rhea are the privileged species that have been commercially used for their meat (Morata 2004). Although, rhea production has started around 1800, the captive breeding of this specie is not given enough attention if compared with ostrich farming (Sales et al. 2000). Thus, rhea production is currently taking place with little information that leads to improve production of this bird. This is partly due to the paucity of meaningful morphological information in the structure of the digestive tract (particularly upper digestive tract) currently available.

In view of the lack of information regarding the gross anatomical features of the upper digestive tract of the rhea, this study provides a detailed description of the macroscopic features of the oral cavity (including the tongue), and pharynx (including the laryngeal mound) and compares the results with published information on ratites and other birds. The terminology used is that of Nomina Anatomica Avium (Baumel et al. 1993).

\section{MATERIALS AND METHODS}

The heads of five young birds aged two to six months were used in the present study. The specimens were collected immediately after death by natural causes, in the Centre for Wild Animals Multiplication (CEMAS), Rural Federal University of Semi Arid (UFERSA), Mossoró/RN, registered with IBAMA as scientific breeding under number 1478912, and immersed in 10\% buffered formaldehyde for a minimum period of 48hours for complete preservation. All management was done according to the indicated by the Ethical Committee of UFERSA. The heads were then removed from the fixative, rinsed in running tap water to remove excess of formalin, and incised along one commissure of the mouth to expose the oropharyngeal cavity. The macroscopical features were described and digitally recorded using Sony MVC-CD500 digital camera (Sony Corporation, Tokyo, Japan). Dried skulls and whole specimens of the tongue, laryngeal mound, trachea and hyoid bone were utilized to provide supporting evidence of the gross anatomical description.
The nomenclature used for the identification of the structures was based on the Handbook of avian anatomy: Nomina Anatomica Avium edited by the International Committee on Avian Anatomical Nomenclature, World Association of Veterinary Anatomists (1994).

\section{RESULTS}

\section{Rostral boundaries of the oropharynx}

The oropharyngeal cavity was bell-shaped (Fig.2) and dorso-ventrally flattened, resulting in limited space within the cavity when the beak was closed. No morphological distinction could be made between the oral cavity and the pharynx and both cavities formed a common chamber, commonly called oropharynx.

The rostral part of the oropharynx (essentially representing the oral cavity) was bounded ventrally by the mandibular ramphotheca and dorsally by the maxillary ramphotheca. The mandibular ramphotheca was a pale, creamy colour and was clearly demarcated from the rest of the floor of the oral cavity with which it was continuous. It extended bilaterally as a zone of cornified epithelium from the angulus oris. The ramphotheca was of equal width where it lay over the ramus of the mandible but widened rostrally to form a plate-like trapezoidal fashion region above the mandibular rostrum (Rostrum mandibulae) (Fig.1B). A variable number of fine, rostro-transversally oriented folds which connect each other at median longitudinal ridge of the interramal region (Regio interramalis) were observed (Fig.2), whereas in the center of the region, immediately rostral to the tongue, fine transverse, circular and oblique folds could
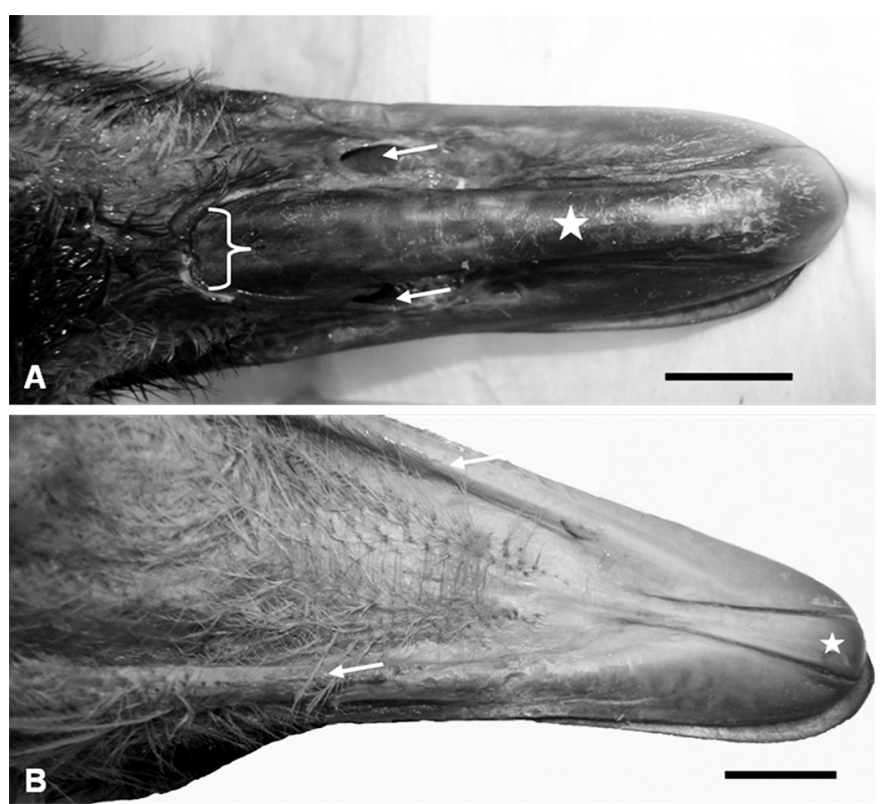

Fig.1. In A dorsal view of rhea upper beak, note the contribution of the mid-dorsal plate of the external ramphotheca (star) of the tomium of the upper beak. The nostrils (arrows) lying on the dorsal surface of the maxillary rhamphotheca slightly before merging in the skin of the forehead as indicated by the curved arrows. In B ventral view of rhea upper beak, the arrows indicate the arms of the mandible that widen rostrally forming a plate-like trapezoidal fashion region (stars) on the mandibular rostrum (rostrum mandibulae). 


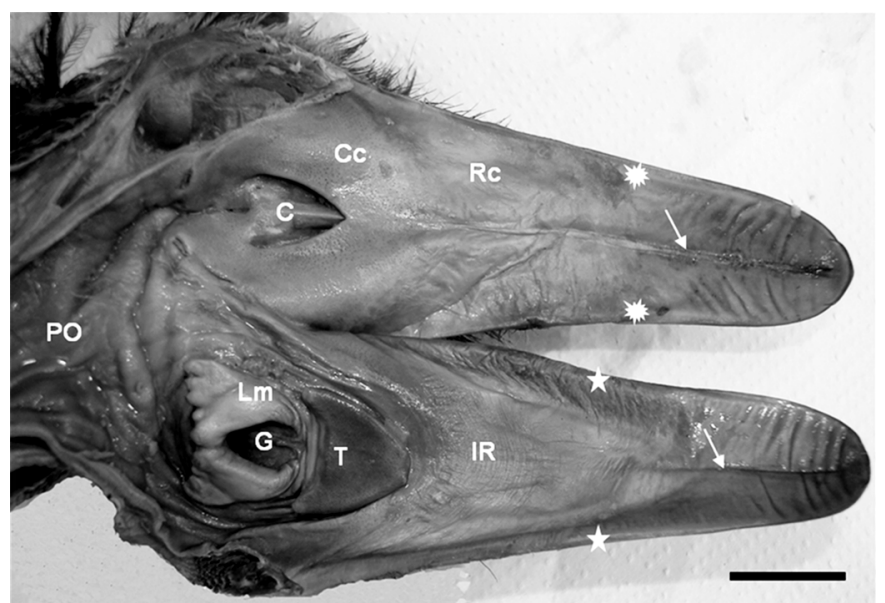

Fig.2. Gross anatomical features of the oropharynx of the Rhea. The beak is divided into maxillary ramphotheca (asterisks) and mandibular ramphotheca (stars). The roof of the oropharynx is clearly divided in two regions: pale rostral component (Rc) and darker caudal component (Cc). Note the median palatine ridge (white arrows) dividing the roof in the midline and the V-shaped choanae (C). The floor of the oropharynx reveals the slightly folded interramal region (regio interramalis) (IR) dominated by a thin median fold (arrow-head) merely restricted to the rostral component (Rc). The caudal component part contains the tongue (T) and the laryngeal mound (Lm) housing the wide opened glottis $(G)$. The mucosa covering the mound was relatively smooth in appearance and was continuous caudally with the prominently folded mucosa of the proximal oesophagus (PO).

be discerned. The raised, sharp edge tomium (Tomium mandibulare) was apparent all along the lateral border of the two thirds of mandibular rami. At the tip of the beak the tomium was interrupted by the rostral termination of the gonys, a midventral, thickened, plate-like trapezoidal fashion component of the external ramphotheca which extended from the tip of the mandible to the skin forming the rostral limit of the interramal region (Regio interramalis) (Fig.1B). The gonys was supported by a broad thickening of the bone on the ventral surface of the mandibular rostrum in the vicinity of the mandibular symphysis (Symphysis mandibularis). The termination of the gonys effectively formed the unguis or nail which was continuous with the tomium. The mandibular gonys was $2,6 \mathrm{~cm}$ long and width of $0,5 \mathrm{~cm}$ as mean values among animals. The remaining lateral surface of the mandibular ramphotheca caudal to the tomium was smooth and rounded.

The maxillary ramphotheca was clearly demarcated from the surrounding tissue as in the mandibular ramphotheca. As in the latter, the tomium appeared along all the way of the two thirds of the maxillary rhamphotheca. The lateral margin of the short caudal maxillary ramphotheca formed, as well as, in the mandibular rhamphotheca, a rounded, cord-like structure which extended from the one third of the rami to the corners of the mouth. At the tip of the beak the tomium was interrupted by the rostral termination of the culmen (a mid-dorsal plate of the external ramphotheca which extended from the tip of the upper beak to the skin of the forehead) (Fig.1A). This structure (effectively the maxillary unguis or nail) was also continuous with the tomium laterally.

The culmen was $5,2 \mathrm{~cm}$ long and width $0,9 \mathrm{~cm}$. It was well demonstrated that the rostral part of the maxillary tomium and the maxillary unguis exhibited a higher profile than the equivalent structures on the mandible. The rostral part of the culmen was supported by a thickening of the dorsal tip of the premaxillary bone providing further support that the termination of the culmen formed a nail (unguis).

\section{Roof of the oropharynx}

The roof of the cavity demonstrated two regions (of approximately equal area) based on differences in the colour of the mucosa. The demarcation of the two regions was abrupt (Fig.3A). The mucosa of the rostral and rostro-lateral region was pale pink, tightly stretched, and divided into two halves by a prominent raised longitudinal mucosal ridge or fold, the median palatine ridge (Ruga palatina mediana). This structure extended rostrally from the apex of the choana to the tip of the beak, ending against the unguis. At a point approximately half way along the median ridge the mucosa in this region displayed prominent transverse mucosal folds which lie rostro-laterally towards the rampotheca (Fig.2).

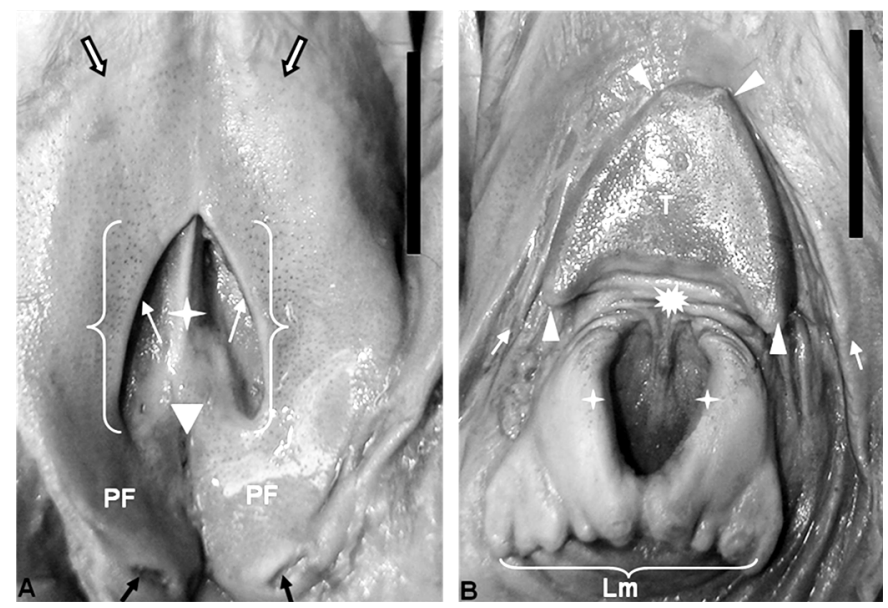

Fig.3. Enlargement of the pharyngeal region (A) and enlargement of the tongue and laryngeal mound (B). In A the abrupt changing (large arrows) of the color between the rostral and caudal components. The choanae (keyway) containing the entrance of the internal nares (white arrows) is separated by a prominent median ridge (white star). The caudal part of the oropharyngeal roof shows the discrete opening of the infudibular cleft (arrowhead) from which a crater-like depression subdivides the caudal portion of pharyngeal mucosa into two mucosal folds (PF). Note the two discrete openings (black arrows) dorsomedially in the PF immediately before merging lightly with the mucosa of the proximal oesophagus. In B observe the horseshoe-shaped tongue (T) and laryngeal mound (Lm) illustrating the typical glove-shaped appearance of this region. Note the caudally directed papillae at the base (arrowheads) and the two pit-like structures in the apex of the tongue. The prominent lips of the glottis (star) connect each other in the midline caudally. Note the stretched nature of the undersized mucosa between the tongue and entrance of the glottis (asterisks) and the two major mucosal fold (white arrows) surrounding the glottis continuous caudally with the oesophageal mucosa. 
The mucosa of the caudal and caudo-medial region surrounding the choana and the opening of Eustachian tubes was pale grey coloured, with a sponge-like texture. When viewed from beneath, the choana formed a inverted $\mathrm{V}$-shaped depression (with the apex of the $\mathrm{V}$ facing rostrally), subdivided along the midline by a prominent mucosal ridge. The ridge was deeper rostrally where it inserted arrowhead-like into the apex of the choana. It became shallower caudally where it weakens just before the rostral boundary of the infundibular cleft. At the lateral borders of the choana lay the openings of the internal nares, each demarcated dorso-medially by a low mucosal ridge (Fig.2 and $3 \mathrm{~A}$ ).

Caudal to the choana was the median infundibular cleft (Rima infundibuli) which represented the opening to the pharynx of the left and right Eustachian tubes opening. The infundibular cleft extended from a crater-like depression lying caudal to the crescent-shaped ridge of the choana (described above). Caudally to the opening of the Eustachian tubes, the mucosa was subdivided into two pharyngeal folds. These folds presented in the dorsomedial aspect two discrete openings, and ventro-caudally a shallow recess continuous with the oesophageal mucosa (Fig.2 and $3 \mathrm{~A}$ ). The thickened nature of the mucosa in this region was probably due to the presence of numerous, well-developed mucous-producing glands. The openings of these glands could be seen as small pit-like depressions throughout the surface of this region.

\section{Floor of the oropharynx}

The floor of the oropharynx was formed by the interramal region (Regio interramalis), the tongue and the laryngeal mound (Fig.2). The triangular interramal region (Regio interralamis) was accommodated between the rami of the mandible and formed the floor of the oral cavity rostral to the tongue. It extended bilaterally around both the tongue and the laryngeal mound, eventually merging caudally with the oesophageal mucosa. The mucosa of this region displayed two components based on differences in colour. The largest component was a pale pink colour and occupied the rostral and rostro-lateral aspects of the oral cavity. The smaller pale grey component (darker) occupied a limited area in the immediate vicinity of the tongue, both rostrally and laterally (Fig.2), curved around the laryngeal mound, and represented that part of the interramal region (Regio interramalis) that merged with the oesophageal mucosa.

The entire interramal region (regio interramalis) was characterised by a softly folded mucosa, the most obvious of these was one which surrounds the laryngeal mound (in each side) and the tongue towards the oesophagus. In similar fashion to that of the median palatine ridge, the midline fold in the floor of the oropharynx continued rostrally, effectively dividing the ramphotheca covering the mandibular rostrum into two halves before narrowing to terminate against the mandibular unguis. Unlike the median palatine ridge, the median fold was fleshy in nature and displayed vertical pattern merely restricted to the rostral part of the rostral component (Fig.2).

One additional set of folds were observed to originate from the floor of the pharynx on either side of the laryngeal mound. Each set consisted of approximately two longitudinal folds, the largest of which was laterally positioned and emanated from the caudo-lateral borders of the tongue. Although most of the smaller folds in this region were longitudinally oriented, numerous oblique and transverse folds were observed to link each other branched mainly in the rostral aspect of the tongue and in the interramal region (Regio interramalis). The most medially positioned folds branched circularly surround the laryngeal mound, and extended from the caudal and caudo-lateral aspects of the body of the tongue, coursing around the laryngeal mound to merge with the criss-crossing folds of the widened portion of the proximal oesophagus. (Fig.2 and 3B).

The Rhea tongue was a small, fusiform, horseshoe-shaped structure that lay approximately in the middle of the floor of the oropharynx. It was grey color and had a firm texture in the specimens studied. From the blunt apex the body widened caudally forming two short arms, each of which terminated in an elongated, rounded tip suggestive of a double-shaped papilla (Figs. 2 and 3). Each double-shaped papilla was superimposed to each other by a median fissure which gives it a sandwich appearance. The base of the tongue lay relatively closed from the entrance of the larynx (glottis) and the stretched mucosa between the two structures demonstrated a number of transversal folds (Figs. 2 and 3B). Whether this region represented the root of the tongue was morphologically difficult to determine. With the beak closed the tongue fitted against the pale grey mucosa around the rostral aspect of the choana. The flattened, thickened nature of the tongue resulted in the formation of dorsal and ventral surfaces and lateral borders. All the tongue displayed a subtle, spotted appearance (Fig. 3B). Each rounded unit (spot) contained a centrally positioned opening presumably representing the duct of large mucus-producing glandular units situated in the mucosa.

The dorsal surface of the tongue presented at the tip of the organ two pit-like structures firm in texture but light in color resembling cartilage. Midsagitally sections of the tongue revealed that it was composed by muscle and cartilage. The cartilage lies all the way of the body of the organ and began at the half way of the tongue to the tip of it. The ventral aspect of the tongue was attached to the floor of the oropharynx by numerous mucosal folds. No frenulum (Frenulum linguae) was observed. It was seen that the smooth mucosa of the ventral tongue replaces the frenulum and displayed numerous folds with branched longitudinal folds being particularly more obvious along the lateral edges (Fig.3B). It was also clear from median sections that the body of the tongue was supported by cartilaginous part of the hyoid bone whereas the root was supported by the ossified part of the body of the larynx.

A short distance from the base of the tongue was the laryngeal mound, a raised oval in the center and a glove-shaped structure which occupied the caudal third of the floor of the oropharyngeal cavity. It was related rostrally to the base of the tongue and caudally to the oesophagus. The more rostral glove-shaped portion of the mound, housed the glottis, a wide opened structure exhibiting a U-shaped 
fashion, with the arms of the $U$ directed rostro-laterally (Fig.2 and 3B). The rim of the glottis was demarcated by two prominent mucosal ridges or lips which were elevated above the surface of the mound. The lips meet at the base of the glottis, leaving a depression-like fissure between them (Fig.2 and 3B). When the beak was closed, the glottis was perfectly aligned with the common openings of the choana in the caudal region of the roof of the oropharynx.

The rostral portion of the mound housing the glottis was inclined in a dorso-rostral direction (Fig.2 and 3). The caudo-medial glove-shaped structure appeared to form a paired structure, where subtle grooves could be discerned between the projections (Fig.2 and 3B). Those projections were bulbous in nature with intervening grooves giving them the appearance of papillae (Fig. 3B). The more caudal aspect of the laryngeal mound was structurally simple and presented a slight recess before continuing as oesophageal mucosa.

\section{General features}

\section{DISCUSSION}

The classical descriptions of the avian oral and pharyngeal cavities previously described (Göppert 1903, Farner \& King 1972, McLelland 1979, 1993, Bezuidenhout 1999) are similar to those verified in the rhea. As noted in the results, no obvious morphological distinction could be made between the oral cavity and the pharynx and both cavities formed a common chamber. This situation apparently occurs in most avian species due to the absence of a soft palate and oropharyngeal isthmus (McLelland 1979, 1993). However, Zweers et al. (1977) described a margin between both cavities at the level of the caudal lingual papillae in the mallard. It has been reported by Gussekloo (2006) that in ratites although the ramphotheca forms the rim of the oral cavity it "shows very little adaptation and the rims are relatively rounded and blunted". Such statement differ from those found by us, where it was observed that only the most rostral component of both the mandibular and maxillary ramphotheca possess a raised, sharp edge, the tomium located along the lateral border, whereas the caudal aspect of the ramphotheca was smooth and rounded. Similar characteristics were also observed by Crole \& Soley (2010) in emu (Dromaius novaehollandiae). However, the existence of this structural adaptation would lend support to the observation that rhea generally inclines the head and use their large beaks to tear off plant material during feeding (personal observation - M.F. Oliveira, 2009). The distinct difference in width observed between the mandibular and maxillary ramphotheca has been illustrated in the rhea (Gussekloo \& Bout 2005).

\section{Roof of the oropharynx}

The roof of the oropharynx exhibited the basic features previously described and illustrated in many species of birds (McLelland 1979).

Although had been demonstrated in various avian species, that the mucosa of the palate frequently forms lateral, median and intermediate ridges (McLelland 1979), the mucosa of the palate in the rhea formed a single median longitudinal ridge (Ruga palatina mediana) which extended the length of the palate rostral to the tip of the choana. This result corroborate with those reported by Gussekloo \& Bout (2005) and Gussekloo (2006) in the rhea, by Tivane (2011) in the ostrich, and by Crole \& Soley (2010) in the emu. Different to what have been demonstrated by these authors and from those found by us, Tadjalli et al. (2008) described this structure in the ostrich as "median longitudinal mucosal fold".

As illustrated by Gussekloo \& Bout (2005) and confirmed in the present study, the choana in the rhea is very short and restricted to the caudal aspect of the palate, a feature shared with ostrich (Tivane 2011), emu (Crole \& Soley 2010) and few other species such as herons and ducks (McLelland 1979). Therefore, contrarily the ostrich choana which presents a double layer-structure, the rhea choana is demarcated dorso-medially by a single low mucosal ridge. The illustration of the oropharynx of the rhea provided by Gussekloo \& Bout (2005) supports this evidence.

Likewise, as determined in the present study, the caudally directed papillae that reportedly form a typical feature of the palate and roof of the pharynx in many avian species (Göppert1903, McLelland 1979) are totally absent in the rhea (Gussekloo \& Bout 2005).

The remarkable finding of the present study was the division of the palate into two distinct regions based on differences in the color of the mucosa. This finding seems to approach to the illustration of the ostrich oropharynx by Göppert (1903) which also appears to indicate this regional differentiation. However, histological results of this region in the ostrich revealed that this distinction was due to the presence of mucus-secreting glands in the darker region surrounding the choana and extending onto the pharyngeal folds (Tivane 2011). Reverse situation was described by Crole \& Soley (2010) in the emu. The authors observed pigmented area in the rostral region while the non-pigmented region was confined to the caudal part of the oropharynx.

The most obvious features of the pharynx observed in this study were the presence of two pharyngeal folds separated by a deeper median sulcus which originates in a short pharyngeal cleft (Rima infundibuli). Such data are different by those found in the ostrich by Tivane (2011) and in the emu (Crole \& Soley 2010). The pharyngeal cleft was described as a median longitudinal fissure which connects the infundibulum (into which the common Eustachian tubes [Tubae auditivae] opening) to the pharynx (McLelland $1979,1993)$. The observation that the auditory tubes open independently into the infundibulum in ratites, contrarily the mentioned opening via a common tube in the chicken and dove (McLelland 1993) was not confirmed in the present study.

It has been reported that the region around the pharyngeal folds in the ostrich (Tivane 2011) and in the emu (Crole \& Soley 2010) were seen to overlap in the midline and that these structures contained mucus-secreting glands and masses of lymphoid tissue, thus constituting pharyngeal tonsils (McLelland (1979). Additionally, the latter states that these structures make "a sharp boundary with the oesophagus". Such statement was fully supported by Ti- 
vane (2011) and Crole \& Soley (2010) studies respectively, but differ from ours where it was seen that the pharyngeal folds do not overlap and form caudally a shallow recess before merging with the tissue of the proximal oesophagus.

\section{Floor of the oropharynx}

This study demonstrated that the floor of the oropharynx of the rhea consisted of three components, the interramal region (Regio interramalis), the tongue and the laryngeal mound (Mons laryngealis). The interramal region (Regio interramalis) has previously been mentioned or illustrated in the ostrich (Göppert 1903, Bezuidenhout 1999, Tivane 2011) and in the emu (Crole \& Soley 2010). Similarly to Gussekloo \& Bout (2005) and Gussekloo (2006) studies, we noticed that this region was slightly folded, with the most prominent feature being a single large median mucosal fold that effectively divided only the rostral part (pale pink in color) of the interramal region (Regio interramalis) into two halves. It has been suggested by Gussekloo \& Bout (2005) studies and supported by Tivane (2011) and Crole \& Soley (2010), that the folded nature of the mucosa of the interramal region (Regio interramalis) in the referred species of ratites, would indicate that this region can be distended to accommodate the accumulation of food and/or water in the oral cavity prior to deglutition.

This study confirmed the basic observation by previous authors (Faraggiana 1933, Cho et al. 1984, Fowler 1991, Bezuidenhout 1999, Rodrigues 2012) that the rhea tongue is dark coloured small, triangular or V-shaped, and has a flat rigid appearance. Although flat, the surface of the rhea tongue has a spotted appearance. Were believed that this appearance was apparently due to the presence of large mucus-producing glands located just beneath the surface as reported (Faraggiana 1933, Tivane 2011, Crole \& Soley 2009, Rodrigues 2012).

The present work also confirmed the observations of Rodrigues, 2012 who observed that the caudal aspect of the body of the tongue tapered bilaterally to form papillae-like extensions made of cartilage. However, although lingual papillae in the tongue of various avian species had been reported (Göppert 1903, Gardner 1926, 1927, McLelland 1979, Kobayashi et al. 1998, Nickel et al. 1977), the presence of this structure in ratites is unclear and generates contradictory information. Gadow (1879) assumed that the small caudally directed points on the lateral edges of cassowary tongue would represent lingual papillae. Gussekloo (2006) notes that in ratites "only the papillae behind the larynx (papillae pharyngis caudoventrales) are clearly recognizable", whereas Tomlinson (2000), referring on the role of the ratite tongue in pushing a food bolus from the pharynx to the oesophagus, states that "The tongue is therefore very short and relatively broad without clear adaptations other than the papillae linguae caudales which plays a role in stabilizing the food bolus during the final transport into the oesophagus." The structures observed in specimens of the rhea tongue certainly resemble papillae (caudal lingual papillae) and it would appear to be the lingual papillae described by Gussekloo \& Bout (2005) and Rodrigues (2012) in the rhea (Rhea americana americana) tongue.
The flatened rigid appearance of the rhea tongue has previously been described by Rodrigues (2012), and it was confirmed in the present study. The laryngeal mound (Mons laryngealis) in avian species is a raised structure lying immediately caudal to the tongue which carries on its rostral aspect the glottis (McLelland 1979). Similar to most bird species, the laryngeal mound in the rhea was situated very close to the base of the tongue with only a small stretched band of tissue lying between the two structures (McLelland 1979).

In the rhea the part of the mound carrying the glottis was oval in the center and a glove-shaped structure. The glottis typically lay directly opposite the caudal aspect of the choana as described in many avian species (McLelland 1979), and in the ostrich (Tivane 2011). It has been well documented that in most species of birds papillae are found in the oropharynx at the edges of the choana, the base of the tongue, and caudal to the larynx and infundibular cleft (Göppert 1903, McLelland 1979, Gussekloo 2006). Based in the Gussekloo (2006) illustrations in the rhea where the author named the papillae at the base of the larynx as Papillae pharyngis caudoventrales, we can suggest that the small projections observed in the caudal part of the glottis of the rhea can be viewed as pharyngeal papillae. Therefore, the illustrations of Tivane (2011) and Rodrigues (2012) seem to support the evidence that ratites oropharynx is generally weakly equipped with papillae. The results obtained from the present study indicate structural similarities between the rhea oropharynx and other birds and leads to the conclusion that the morphological features of the oropharyngeal cavity of the rhea are typically similar to those described in many avian species in general. Additionally, important morphological information not previously described is highlighted in order to support other studies of these birds particularly in respect of nutrition and health.

\section{REFERENCES}

Baumel J.J., King A.S., Breazile J.E., Evans H.E. \& Vanden Berge J.C. 1993. Handbook of Avian Anatomy: Nomina Anatomica Avium. $2^{\text {nd }}$ ed. Nuttall Ornithological Club, Cambridge, Massachusetts, 799p.

Bezuidenhout A.J. 1999. Anatomy, p.13-49. In: Deeming D.C. (Ed.), The Ostrich: Biology, production and health. CABI Publishing, Wallingford, UK.

Cho P., Brown B. \& Anderson M. 1984. Comparative gross anatomy of ratites. Zoo Biology 3:133-144

Crole M.R. \& Soley J.T. 2009. Morphology of the tongue of the emu (Dromaius novaehollandiae). II. Histological features. Onderstepoort J. Vet. Res. 76:347-361.

Crole M.R. \& Soley J.T. 2010. Gross morphology of the intra-oral rhamphotheca, oropharynx and proximal oesophagus of the emu (Dromaius novaehollandiae). Anat. Histol. Embryol. 39:207-218.

Faraggiana R. 1933. Sulla morfologia della lingua e del rialzo laringeo di alcune specie di Uccelli Ratiti e Carenati non comuni. Boll. Musei. Zool. Anat. Comp. 43:313-323.

Farner D.S. \& King J.R. 1972. Avian Biology (K. Parkes, Ed.). Vol.2. Academic Press Pittsburgh, Pennsylvania, p.343-364.

Fowler M.E. 1991 Comparative clinical anatomy of ratites. J. Zoo Wildl. Med. 22:204-227.

Gadow H. 1879. Versuch einer vergleichenden Anatomie des Verdauungssystemes der Vögel. Z. Med. Naturw., Jena, 13:92-171. 
Gardner L.L. 1926. The adaptive modifications and the taxonomic value of the tongue in birds. Proc. United States National Museum 67: Article 19.

Gianonii M.L. 1997. Emas e Avestruzes: uma alternativa para o produtor rural. Funep, Jaboticabal. 49p.

Gussekloo S.W.S. 2006. Feeding structures in birds, p.14-19. In: Bels V. (Ed.), Feeding in Domestic Vertebrates: From structure to behaviour. CABI Publishing, Wallingford, UK.

Gussekloo S.W.S. \& Bout G.R. 2005. The kinematics of feeding and drinking in palaeognathous birds in relation to cranial morphology. J. Exp. Biol. 208:3395-3407.

Göppert E. 1903. Die Bedeutung der Zunge für den sekundären Gaumen und den Ductus nasopharyngeus. Morph. Jahrb. 31:311-359.

Kobayashi K., Kumakura M., Yoshimura M.K., Inatomi M. \& Asami T. 1998. Fine structure of the tongue and lingual papillae of the penguin. Archivum Histologicum Cytologicum 61:37-46.

Mello N.H. 1987. A ficha do bicho: Ema. Globo Rural 5:56-60.

McLelland J. 1979. Digestive system, p.69-92. In: King A.S. \& McLelland J. (Eds), Form and Function in Birds. Vol.1. Academic Press, San Diego, CA.

McLelland J. 1993. Apparatus digestorius [Systema alimentarium], p.301328. In: Baumel J.J., King A.S., Breazile J.E., Evans H.E. \& Van den Berge J.C. (Eds), Handbook of Avian Anatomy: Nomina Anatomica Avium. $2^{\text {nd }}$ ed. Nuttall Ornithological Club, Cambridge, MA.

Morata R.L. 2004. Valores energéticos e digestibilidade de nutrientes de alguns alimentos para ema. Dissertação de Mestrado em Zootecnia, Universidade Federal de Viçosa, Viçosa. 44p.

Rodrigues M.N., Oliveira G.B., Silva R.S.B., Tivane C., Albuquerque J.F.G., Miglino M.A. \& Oliveira M.F. 2012. Macroscopia e topografia do aparelho digestório de emas (Rhea americana americana). Pesq. Vet. Bras. 32:681686.

Nickel R., Schummer A. \& Seiferle E. 1977. Digestive system, p.40-50. In: Ibid. (Eds), Anatomy of the Domestic Birds. Verlag Paul Parey, Berlin.

Sales J., Deeming C.C., Deventer P.J.U., Martella M.B. \& Navarro J.L. 2000. Diurnal time-activity budget of adult Greater Rheas (Rhea Americana) in farming environment. Archiv f. Geflügelkunde 64:5:207-210.

Sick H. 1985. Ornitologia Brasileira. Vol.1. [s. n.], Brasília, p.482.

Tadjalli M., Mansouri S.H. \& Poostpasand A. 2008. Gross anatomy of the oropharyngeal cavity in the ostrich (Struthio camelus) . Iran J. Vet. Res. 9:316-323.

Tivane C., Rodrigues M.N., Soley J.T. \& Groenwald H.B. 2011. Gross anatomical features of the oropharyngeal cavity of the ostrich (Struthio camelus). Pesq. Vet. Bras. 31(6):543-550.

Tomlinson C.A. 2000. Feeding in Palaeognathous Birds, p.359-394. In: Schwenk K. (Ed.), Feeding: Form, function, and evolution in tetrapod vertebrates. Academic Press, San Diego.

Zweers G.A., Gerritsen A.F.C. \& Van Kranengurg-Voogd P.J. 1977. Mechanims of feeding of the Mallard (Anas platyrhynchos L.; Aves, Anseriformes). Contr. Vert. Evol. 3(IX):436-439. 